\title{
The Imperative of E - Participation in Sustainable Community Development in Ghana
}

\author{
Francis Kyere \& Naana Yaa Gyamea Kumah \\ University of Electronic Science and Technology of China, China
}

Received: Oct. 30, 2017 Accepted: Nov. 22, 2017 Online published: Nov. 26, 2017

doi:10.5296/jpag.v7i4.12197ＵRL: https://doi.org/10.5296/jpag.v7i4.12197

\begin{abstract}
The study examines some relevance of e- participation in achieving sustainable community development in Ghana. Information and Communication Technology has created an avenue to promote participation, transparency and trust when adopted by government. As a newly discovered political tool, ICT serves as a toolbox for reaching out and engaging the public on governmental policies thereby drawing government closer to citizens in policy and decision making. Through the use of secondary data, the study highlights the necessity for ICT and mostly importantly e-participation adoption in local government administration in Ghana. Citizens having enough access to their elected representatives and some basic public services through the provision of information communication and technology ensures effective and efficient communication between the government and the people at the local level, while it also provides a door for the citizens to receive feedbacks from the right local government quarters. The study concludes that e- participation enhances effective and efficient government service delivery and enhancing citizen's active participation in local governance to ensure sustainable development.

The paper recommends that the in other to ensure active participation of citizens, government should provide the necessary infrastructure and fast track the adoption of ICT and also the training of local government personnel in the art of e- participation through which sustainable community development can be fully attained in Ghana
\end{abstract}

Keywords: e-participation, participation, information communication technology, edemocracy, local government

\section{Introduction}

The potential for Information Communication and Technology to increase community participation in political discourse and address the declining citizen participation in government policies and decisions in Ghana has long been a subject for academic deliberation. 
Citizen participation in public decision making is rooted as a channel for creating democratic and instrument values (Moynihan, 2003).

Governments have a duty encourage its citizens to actively participate in public decision making processes. The notion of e-participation does not replace the traditional forms of citizen engagement but complements it by expanding government's toolbox for reaching out to citizens (UN, 2014).

Application of e- participation has been a fundamental channel in distributing public information, consulting, enhancing active citizen's participation, providing feedback to the citizens, monitoring and evaluating government projects and its implementation as well as making government responsive, accountable and transparent in its total political discourse.

The last two decades has witnessed the adoption of ICT to engage citizens in the decision-making process (Medaglia, 2012) and to salvage the growing canker of citizen's apathy towards governance (Sæbø, Rose, \& Flak, 2008)

This area of interest, termed e-participation, focuses on processes and structures through which ICT supports relationships amongst citizens, governments and public organizations. E-Participation initiatives may change the political landscape (Sandoval-Almazan \& Gil-Garcia, 2016) and introduce opportunities for communication, consultation and dialogue between public organizations and citizens.

E-participation posit as an evaluatory instrument for measuring performance of governments in the developed world. Such countries include Korea, United Kingdom, France and Netherlands. Also, it promotes transparency in all government activities and facilitates citizen access to basic government services. Similarly, e-participation as indicated by the UN survey report (2014) may be viewed from the lens of government performance in electronic medium to enhance expedient information access and delivery to all stakeholders within the economy

Towards this end, cyber-optimists anticipate the immeasurable benefits of enhancing citizen-government interaction through the creation of new communication medium and revitalizing the role of government executives in representative democracies (Norris, 2000).

A few developing nations such as Morocco, Kenya and India have also adopted e-participation for public activities. A case worth mentioning is India's e-participation pilot project that seeks to provide better services and improve citizen's involvement in government. Other countries such as Ghana continuously making strides in all spheres of e-government initiatives of which e-participation lies at its heart. Although the E-GIF policy document indicated Ghana's ICT environment being a greenfield especially in e-government initiatives and systems management, current statistics of internet and mobile phone users reveal a favorable condition available for e-participation. According to the World Factbook, 9,328,018 Ghanaians representing $34.7 \%$ of the total population are internet users (Central Intelligence Agency, 2016). Also there has been a surge in mobile data subscription as indicated by the National Communication Authority in Ghana providing substantial evidence of access to technological infrastructure (National Communications Authority, 2017). Furthermore, the E-GIF places premium emphasis on achieving an all-inclusive online participation as an 
important part of policy development, service delivery and making the democratic process electronic.

Across the various continents, information and communication technology is increasingly being adopted to promote ideals of participatory democracy and advance government's service delivery (Sier ,2005). E-participation therefore revolves around the usage of modern Information Communication and Technology which includes internet, local area networks and smart gadgets in governance.

Local government was designed to narrow the social distance between citizens and the government and promote inclusive governance, a tool for ensuring sustainable community development. In Ghana, there seems to be little evidence of the involvement of the local people in development planning in Ghana. As indicated in various researches (Ahenkan, Bawole, \& Domfeh, 2013; Bebelleh \& Nobabumah, 2013; Zakari, 2012), there has been a desire by the youth who form a majority of Ghana's population to participate in decision making which can lead to sustainable community development. However, insufficient mechanisms for participation and even so the available traditional mechanisms do not offer them the opportunity to influence governmental policies. Thus, information and communication technology if adopted at local level units can provide substantial benefits in meeting objectives for its creation although the expectations often differ. It therefore makes e-participation, an instrumental political device to achieve better governance and development at the local level.

It is against this backdrop that this study examines e-participation as an essential political mechanism through which sustainable community development in Ghana's decentralized systems can be realized. the realization of sustainable community development through the decentralized systems could be attained in Ghana.

\section{Conceptual Framework}

World Bank defines participation as "a process through which stakeholders' influence and share control over development initiatives, decisions, and resources which affect them" (cited in Ondik, 2003). Public dissatisfaction with modern democratic practices especially in Africa is more prevalent than ever. Social exclusion and other effects of economic reorganization have called for a fresh interest in citizen participation and citizen engagement (Cooper, Bryer, \& Meek, 2006; Smyth \& Reddel, 2000) and diverse levels in academic and political discourse of ideas and values of community, localism and citizen participation. Citizen participation in decision making is known to have a greater positive impacts on citizens trust and confidence in government (Cooper et al., 2006; K. Yang, 2005) government's legitimacy (Fung, 2006), and responsiveness (K. F. Yang \& Holzer, 2006). The concept of e-democracy, meaning the use of ICT to support a democratic decision-making process (Bruno, 2015), has been widely discussed in a long while for different reasons. The development of technology has made ICTs central to citizens' daily lives and progressively relevant for political systems. Citizens are increasingly questioning traditional forms of representative democracy and expecting innovation in policy-making processes with possibilities of direct participation. This is mainly due to the challenges democratic countries especially in Africa are facing, such as the 
gap between the political elites and the citizens, which leads to the problem of political disengagement. Furthermore, citizens perceive the limits of public institutions' capacity to respond to their demands and a lack of legitimacy in institutional processes at all levels. There is a need to revive democratic societies and to enhance a more deliberative view of active citizenship through more direct engagement (Cbased.com, 2015).

E-participation is one important dimension of e-government, which relates to the effects of ICTs on government-citizen's relations. The term 'e-participation' suffers from a lack of an all-inclusive definition, as it comprises a wide range of initiatives. For example, it could mean the use of ICT by a government to enhance openness and transparency by the provision of information online, or the use of ICT by citizens to participate, collaborate or/and deliberate in a decision-making process. In this study, the UN survey 2014's meaning is adopted to define e-participation. According to UN (2014), "e-participation is the process of engaging citizens through Information Communication and Technology in policy and decision making in order to make public administration participatory, inclusive, collaborative and deliberative for intrinsic and instrumental ends." Under this circumstance, e-participation may be referred to as using information and communication technology in all activities of governance with the aim of awareness creation, achieving transparency and accountability, and facilitating interaction in the form of information delivery and exchange between government and citizens.

E-participation stands for electronic-participation and has its goals of engaging, enabling and empowering the citizenry (UNESCO, 2005).

\subsection{E-Participation Model}

Citizen participation is more often than not equated to voting in elections, however public participation and citizen engagement extends to influencing public policies and service delivery.

OECD's (2001) framework on e-Participation, a well-known framework comprises of i) information, ii) consultation and iii) active participation (decision making). Similarly, a three level of participation is developed which includes (1) e-enabling, (2) e-engaging and (3) e-empowering by Macintosh, (2004) based on OECD's framework. The e-empowering stage is the peak of the model and citizens are actively involved and viewed as development partners who can provide ideas through the bottom-up approach in the political process. Furthermore, the UN survey 2014's e-participation framework is no different from the aforementioned. Also based on a three level dimension with the first stage being e-information, followed by e-consultation and e-decision making. 


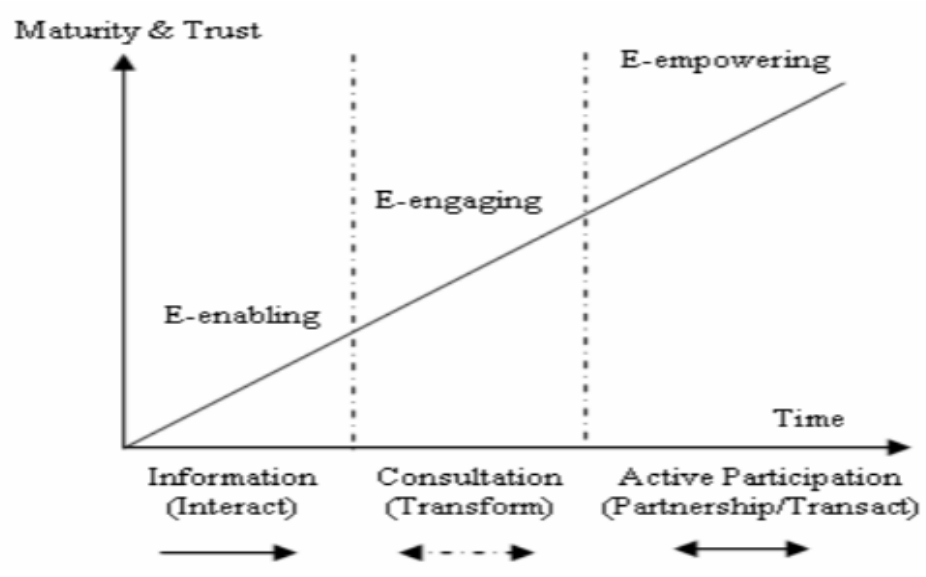

Figure 1. Integrated dimension of E-Participation (Phang \& Kankanhalli, 2007)

Information, the first level enables citizens to access government information passively. Citizens are only informed on issues with no appropriate mechanisms to engage them. Although a one-way activity, it is essential for active participation to take place. Without timely and accurate information about a policy related issue, citizens cannot contribute effectively in decision making. It is therefore imperative that citizens are provided public information upon demand.

Consultation: this level has to do with the use of technology with citizens which has a broader spectrum of engagement that enables not only contribution but deliberation during policy making. The term "to consult" in this context refers to government consulting citizens and the two-way communication in which government solicit for citizens engagement and citizens provide government with their opinions, issues and needs (Macintosh, 2006).

Active participation: citizens are capacitated through collaborating and partnering with government so as to be actively and independently involved in the policymaking process. The government takes into account the input of citizens in its decisions and informs them of what decisions have been taken following the consultation process. This assumes that citizens have not only expressed their opinions, but that they have also proven their willingness to monitor change. This dimension usually exhibits the level of e-participation over time and possesses positive correlation between a certain level of maturity and trust in the government. However, the model is inadequate for building an e-participation architecture since it doesn't provide guidelines on how this level is reached over time. Basic understanding of the levels of participation stems from the overall e-government progress of a country.

\subsection{Development Defined}

Development as a concept has varied meanings and perspectives informed by different school of thoughts. The concept could be defined along economic growth as well as from the social wellbeing perspective. In spite of these variations, development in its basic sense refers to sustained growth.

Walter (1973) describes development as a multi-dimensional process that involves the complete transformation of the entire economic and social system. As widely accepted in 
current discourses, Todaro provides a comprehensive understanding of development from the social and economic viewpoints. "Development is the improvement of income and output radical changes in institutional, social and administrative structures as well as in popular attitudes, customs and belief" according to Todaro (1982 cited in Ikeanyibe, 2009)). More consistent with the above, development may be defined as positive transformation in social, political, economic and institutional structures of a nation. This definition also denotes a broader view of development that covers all aspects of a country's sector. It involves taking great initiatives that optimizes people's welfare in its entirety in terms of psychological, social, emotional or intellectual well-being

Development is a continuous process hence must meet expectations at varied times. This brings to light the concept of sustainable development. When development meets the demands and needs of the current generation without compromising that of future ones, sustainable development has been achieved as highlighted by The United Nations World Commission on Environment and Development (Brundtland, 1987).

\subsection{Community Development Defined}

According to United Nations, community development involves the participation of an entire community to create conducive conditions for economic and social progress. Similarly, it is viewed as community members coming together to take collective action and developing solutions to common problems. It involves engaging communities in policy making, planning, program development and evaluation. Basically, community development is a bottom up approach in governance (Western Australia. Department of Local Government and Communities, 2015). Elected Public participation was designed to narrow the social distance between citizens and the government in Ghana but there seem to be little to show for the involvement of the local people in development planning in Ghana. Research reveals that the youth who form a majority of Ghana's population have the desire and interest to participate in decision making to ensure sustainable community development, but there seems to be insufficient mechanisms for participation and even so the available traditional mechanisms do not offer them the opportunity to influence governmental policies (Ahenkan et al., 2013; Bebelleh \& Nobabumah, 2013; Zakari, 2012). These researches also indicated that community members are mostly apathetic about community development because the local authority provides them with little or no information on development issues. This shows that generally the level of participation and influence in community development among the stakeholders in the district is low because most of the people, particularly the farmers, youth, women and opinion leaders lack proper understanding of the processes and procedures with which development policies are formulated in the district assemblies which are necessary for the promotion of an effective, responsive and responsible government at the local level.

With the advent of ICT tools and the changing nature of governance, e-participation holds the promise of convenience and accelerating growth within a community.

\subsection{Benchmark Analysis to Understand E-Participation Readiness}

The cornerstone of social inclusive governance is the promotion of citizen participation in 
public decision making. E-participation initiatives have the paramount aim of enhancing information and service delivery and enlisting public participation which could lead to positive impacts on the social wellbeing.

Benchmarking studies enables policy makers and shareholders to compare the standing of their country in terms of others and assist them to adopt strategic decision-making on e-Democracy and e-Governance at large. This also provides civil society an accountability toolbox for the resources they have invested on (Heeks, 2006). The UN global e-government Survey, a biennial report makes available comparative rankings of all its member states based on the state of e-government readiness and the extent of e-participation using its well established measurement index. The countries are ranked through the survey according to a numerical classification corresponding to the five stages of presence: Emerging, Enhanced, Interactive, Transactional and Networked. Based on this survey, however, these may give some clues on the standing of countries' readiness for e-participation.

The use of digital technologies i.e. advanced electronic and mobile services is gaining popularity among governments evident in the various sectors of the economy, although disparity exists. These new developments not only seek to promote sustainable development and provision of better services. Opportunities for social inclusion, equity and fairness are harnessed. In the African context, ICT for governance is being exploited amidst the challenge of narrowing the digital divide. Further policies are required to strengthen institutions and promote the general well-being of all.

The Survey assessed the technical features of national websites as well as e-government policies and strategies applied in general and by specific sectors for delivery of services. On a scale from zero to one, one corresponding to the highest rated online services and zero to the lowest. Country's online performance are measured relative to one another and the variation between scores shows the gap in online service delivery. A high score only indicates best current practice and vice versa.

As a matter of importance, proponents of the information age strongly believed the potency of new forms of political participation enabled by networked communications, such as e-participation, would increase political processes, particularly the individual's or group's ability to actively participate in democratic decision-making. Undoubtedly, the engagement of virtual citizens empowered to sign electronic petitions, participate in online discussions, forums and collaborate in online deliberative events was praised by enthusiasts as a sign of new paradigm that would see fewer of the persistent problems with lack of public trust, dissatisfaction and reduce citizens' wide political passivity (Boggs, 2001) in liberal democratic systems.

On the other hand, some scholars express the fear that such direct democracy will contribute to nothing more than mob rule and careless policymaking, and that the abundance of information provided by the Internet will add to frequent misinformation that makes sensible political dialogue impossible(Hill \& Hughes, 1998).Regardless of this opinion and other critiques (see Breindl, 2010), the new ICTs and especially e-participation tools, services and collaboration activities are being championed by variety of authorities, policymakers and 


\section{Macrothink}

Journal of Public Administration and Governance

ISSN 2161-7104

2017, Vol. 7, No. 4

other more or less institutionalized actors as invaluable features of the information-based network society and conceived as improving society (Spirakis, Spiraki, \& Nikolopoulos, 2010).

Table 1. Top performing 20 countries in online service index (osi), 2016

\begin{tabular}{ll}
\hline Country & Online Service Index OSI \\
\hline United Kingdom of Great Britain and Northern Ireland & 1 \\
\hline Australia & 0.9783 \\
\hline Singapore & 0.9710 \\
\hline Canadi & 0.9565 \\
\hline Republic of Korea & 0.9420 \\
\hline Finland & 0.9420 \\
\hline New Zealand & 0.9420 \\
\hline France & 0.9420 \\
\hline Nethellands & 0.9275 \\
\hline United States of America & 0.9275 \\
\hline Austria & 0.9130 \\
\hline Spain & 0.9130 \\
\hline Estonia & 0.8913 \\
\hline United Arab Emirates & 0.8913 \\
\hline Sweden & 0.8768 \\
\hline Japan & 0.8768 \\
\hline Italy & 0.8696 \\
\hline Israel & 0.8623 \\
\hline Slovenia & 0.8478 \\
\hline Merico & 0.8478 \\
\hline
\end{tabular}

\section{E-Participation and Community Development in Ghana}

As Wasserman (2011) contends, in relation to Africa, "The widespread uptake of mobile phones and technological devices has led to renewed optimism about the potential they hold for stimulating political participation and widening democratic debate."

Like other African countries, Ghana has witnessed exponential growth in mobile phone access, technological upgrade and subscriptions, in tandem with the consolidation of its democracy. In the administration of local governments, well established frameworks and a conducive environment for ICT implementation strategies is imperative. Accessibility, content, service delivery and the development is the pivot around which local governance ICTs revolves. As a key stakeholder, local governments must put in place a well-integrated, dynamic and citizen centric institution that is accessible to all (CPSI, 2005; Rahman, 2011).

This socio-technological shift requires local government to adopt a new form of governance that is based on online participation and the co-production of services with citizens and 
communities (Magele, 2012). Cramped spaces; shabby ambience; discourteous dealing personnel and their chronic absenteeism; demands of gratification; inefficiency in work; long queues; procrastinating officials; procedural complexities; etc., were some of the undesirable features of the working of the government departments.

The recent development in information and communication technology provides opportunities for bridging the gap between the government and the citizens. The near inaccessibility of basic modern communication technology at the community level has been a hurdle thwarting efforts of enlisting citizen's participation and good service delivery in Ghana. Complementarily, in terms of ultra-modern technology, the local government organization structure is not well equipped. From this, the call for information and communication technology as a tool to accelerate the drive towards sustainable community development in Ghana needs to be intensified. As highlighted in some researches, substantial evidence and results have found the capability of e-governance to promote participatory democracy at the community level. Sachdeva (2002) reiterates the benefits of e-democracy as transforming citizen's role from passive to active participation. Also, government-citizen relations are strengthened and spaces are made available for citizens to make inputs on policymaking via online platforms. The adoption of e-participation not only delivers effective participation but also ensures effective communication. Through online medium, government units can swiftly respond to citizen's questions and demands

As mentioned earlier, at the core of e-participation adoption is the quest to enhance good governance which is generally characterized by active participation, transparency, accountability, and responsiveness (Saparniene \& Valukonyte, 2007). Alongside good governance, e-participation has a ripple effect of transforming the entire economy. Transaction costs are lowered, governments become efficient and citizen centered.

For all countries such as Ghana that have formed synergies and made resolutions of combating the canker of poverty and striving for accelerated development, e-participation is a valuable asset. A reiteration of e-participation's ripple effect is evident in its contribution of creating new job avenues and fostering development of businesses. In essence, e-participation can contribute to capacity-building in Africa (UNESCO, 2007). Also, governments can easily store data and access it aside lessening the processes of data collection, analysis and audit.

In Ghana, the presence of communication networks and internet facilities can facilitate e-participation at the local level. According to NCA, the total subscriptions of mobile data recorded in Ghana as at the end of July was 22,103,467 with a penetration rate of $77.58 \%$. Also, the country can boast of $4 \mathrm{G}$ internet service providers. Indeed communication networks are spanning across all continents and facilitating easy interactions among various units in society (Dawes, 2008). With the current infrastructure and internet penetration rate in Ghana, e-participation can be exploited at all municipal and local units for an all-inclusive development (Abrahams \& Newton-Reid, 2008). It is worth emphasizing that, although ICTS can greatly contribute to informatization and participation, the development of a service delivery model cushions e-governance initiatives (Nuggehalli, 2009).

Last but not the least, the compression of space and time due to advancement in technologies 
is providing avenues for sustainable development although setbacks prevail. Most people can readily access ICT services regardless of the environment they are found in. This is gradually closing the urban and rural divide and the social distance that existed between few political elite and the citizens.

\section{Conclusion and Recommendations}

The fact still remains that increasing citizen's influence and participation in policy-making does not mean replacing the system of rules and principles of representative democracy but rather to respond to citizens' demands of greater level of participation, openness and transparency in a democracy, which is currently evolving. The UN also stresses this point by adding that the promotion of participation in public decision-making can impact the well-being of society in general and of individuals in particular. This study looked at e-participation as an indispensable tool and the need for its adoption to attain sustainable community development in Ghana.

E-participation propels the quest for good governance at all levels of government most especially at the local level. As a political strategy, it holds the potential to complement and strengthen the decentralized structures to effectively engage citizens. This study therefore advocates for the institutionalization of e-participation not only at the national level but at the local levels too. All necessary platforms and initiatives such as public sensitization and training of local government personnel must be provided to reap its maximum benefit. Lastly, private and public actors are encouraged to support initiatives and utilize them.

\section{Acknowledgement}

The research is financed by Asian Development Bank. No. 2006-A171. Thanks for Prof. AAA BBB, World Technology University.

\section{References}

Abrahams, L., \& Newton, R. L. (2008). Paths and limitations to progress. Journal of Public Administration, 44(4.1), 1010-1025.

Ahenkan, A., Bawole, N. J., \& Domfeh, K. A. (2013). Improving Citizens' Participation in Local Government Planning and Financial Management in Ghana: A Stakeholder Analysis of the Sefwi Wiawso Municipal Assembly. Journal of Public Administration and Governance, 3(2), 191-210. http://doi.org/10.5296/jpag.v3i2.3782

Bebelleh, F. D., \& Nobabumah, A. S. (2013). Political Decentralization and Local Participation in Ghana: Perspectives from the Upper West Region. Public Policy and Administration Research, 3(11), 12-26.

Brundtland, G. H. (1987). Our Common Future: Report of the World Commission on Environment and Development. United Nations Commission, 4. http://doi.org/10.1080/07488008808408783

Bruno, E. (2015). Co-deciding with Citizens: Towards Digital Democracy at EU Level. (Assya Kavrakova, Ed.). Ecas. 
Cbased.com. (2015). Now on discuto.io: digitization and politics. Retrieved from https://www.cbased.com/

Central Intelligence Agency. (2016). WORLD FACTBOOK (2008th ed.). USA: Directorate of Intelligence.

Cooper, T. L., Bryer, T. A., \& Meek, J. W. (2006). Citizen-Centered Collaborative Public Management. Public Administration Review, 66(1), 76-88. https://doi.org/10.1111/j.1540-6210.2006.00668.x

Dawes, S. (2008). The Evolution and Continuing Challenges of E-Governance. Public Administration Review, (Special Issue). https://doi.org/10.1111/j.1540-6210.2008.00981.x

Fung, A. (2006). Varieties of Participation in Complex Governance. Public Administration Review, 66(s1), 66-75. http://doi.org/10.1111/j.1540-6210.2006.00667.x

Heeks, R. (2006). Understanding and Measuring EGovernment: International Benchmarking Studies. In E-Participation and EGovernment: Understanding the Present and Creating the Future, Chapter V, Report of the Ad Hoc Expert Group Meeting at Budapest., New York: United Nations.

Hill, K. A., \& Hughes, J. E. (1998). Cyberpolitics: Citizen activism in the age of the internet. Boston: Rowman \& Littlefield Publishers, Inc.

Ikeanyibe, O. (2009). Development Planning in Nigeria: Reflections on the National Economic Empowerment and Development Strategy (NEEDS) 2003-2007. Kamla Raj. J. Soc. Sci., 20(3), 197-210.

Macintosh, A. (2006). eParticipation in Policy-making: The Research and the Challenges. Exploiting the Knowledge Economy: Issues, Applications, Case Studies (Paul Cunni). Amsterdam: IOS Press.

Magele, C. (2012). How to move from local e-government to collaborative e-governance. Guardian News and Media Limited. Retrieved from http://www.theguardian.com/local-government-network/2012/may/08/local-government-e-cit izenship

Medaglia, R. (2012). eParticipation research: Moving characterization forward (2006-2011). Government Information Quarterly, 29(3), 346-360. http://doi.org/10.1016/j.

Moynihan, D. P. (2003). Normative and instrumental perspectives on public participation citizen summits in Washington, D.C. American Review of Public Administration, 33, 164-188. https://doi.org/10.1177/0275074003251379

National Communications Authority. (2017). Telecom Data Subscription. Retrieved September 4, 2017, from https://nca.org.gh/industry-data-2/market-share-statistics-2/data-3/

Norris, P. (2000). E-Governance. Retrieved from http/www.hks.havard.edu/digitalch6.pdf Nuggehalli, R. (2009). Building an Alternative E-Governance Model: Lessons from e-Gram 
in Gujarat. Retrieved from http://www.itforchange.net/e-gram Palvia SCJ, Sharma SS (2007). E-Government

Ondik, R. S. (2003). Participatory Approaches to National Development Planning. Retrieved from

http://siteresources.worldbank.org/INTEASTASIAPACIFIC/Resources/226262-11431565457 24/Brief_ADB.pdf

Phang, W. C., \& Kankanhalli, A. (2007). A Framework of ICT Exploitation for E-Participation Initiatives. Communications of the ACM.

Rahman, H. (2011). Local E-Government Management: A Wider Window of E-Governance; IGI Global. https://doi.org/10.4018/978-1-60960-497-4.ch008

Sachdeva, S. (2002). E-Governance Strategy in India.

Sæbø, Ø., Rose, J., \& Flak, L. (2008). The shape of eParticipation: Characterizing an emerging research area. Government Information Quarterly, 25(3), 400-428. http://doi.org/10.1016/J.GIQ.2007.04.007

Sandoval, A. R., \& Gil. G. J. R. (2016). Toward an integrative assessment of open government: Proposing conceptual lenses and practical components. Journal of Organizational Computing and Electronic Commerce, 26(1-2), 170-192. http://doi.org/10.1080/10919392.2015.1125190

Saparniene, D., Valukonyte, I. (2007). What is good governance? Retrieved from http://www.unescap.org/pdd/prs/ProjectActivities/Ongoing/gg/governance.asp

Sier, S. (2005). E-governance at the Local Government Level in the Philippines: An Assessment of City Government Websites. Philippine Journal of Development, 32(2).

Smyth, P., \& Reddel, T. (2000). Place management: A new way forward in redressing social exclusion? National Housing Action, 14(2), 9-14.

Spirakis, G., Spiraki, C., \& Nikolopoulos, K. (2010). The impact of electronic government on democracy: E-democracy through e-participation. $E G, 7,75-88$.

UN. (2014). UN E-Government Survey 2014. United Nations Department of Economic and Social Affairs (UNDESA). New York: United Nations. Retrieved from https://publicadministration.un.org/egovkb/en-us/Reports/UN-E-Government-Survey-2014

UNESCO. (2005). E-Governance Capacity Building.

UNESCO. (2007). Curriculum Guide On E-Governance for African Government Institutions.

Walter, R. (1973). How Europe Underdeveloped Africa. Tanzania Publishing House and Bogle L'Ouverture Publications.

Wasserman, H. (2011). Mobile Phones, Popular Media, and Everyday African Democracy: Transmissions and Transgressions. Popular Communication, 9(2), 146-158. http://doi.org/10.1080/15405702.2011.562097 
Western Australia. Department of Local Government and Communities. (2015). Community development: a guide for local government elected members / Department of Local Government and Communities. Perth: Department of Local Government and Communities.

Yang, K. (2005). Public Administrators' Trust in Citizens: A Missing Link in Citizen Involvement Efforts. Public Administration Review, 65(3), 273-285. http://doi.org/10.1111/j.1540-6210.2005.00453.x

Yang, K. F., \& Holzer, M. (2006). The performance-trust link: implications for performance measurement. Public Adm Rev, 66(1), 114-126. https://doi.org/10.1111/j.1540-6210.2006.00560.x

Zakari, B. A. (2012). Decentralization and Community Participation in Ghana: The development of District Development Plans in East Mamprusi District. Institute of Social Studies.

\section{Copyright Disclaimer}

Copyright for this article is retained by the author(s), with first publication rights granted to the journal.

This is an open-access article distributed under the terms and conditions of the Creative Commons Attribution license (http://creativecommons.org/licenses/by/4.0/). 